\title{
Aligning Business Strategic Priorities and Purchasing Practices in Industrial Firms: Evidence from an Emerging Economy
}

\author{
Ghazi Samawi ${ }^{*}$, Ismail Abushaikha1, Loay Salhieh ${ }^{2}$, Metri Mdanat ${ }^{1}$, \\ Abdelsalam Al-Rashid ${ }^{3}$ \\ ${ }^{1}$ School of Management and Logistic Sciences, German Jordanian University, Amman, Jordan \\ ${ }^{2}$ Graduate School of Business Administration, German Jordanian University, Amman, Jordan \\ ${ }^{3}$ Mutah University, Mutah, Jordan \\ Email: *ghazi.samawi@gju.edu.jo
}

How to cite this paper: Samawi, G., Abushaikha, I., Salhieh, L., Mdanat, M. and Al-Rashid, A. (2019) Aligning Business Strategic Priorities and Purchasing Practices in Industrial Firms: Evidence from an Emerging Economy. Theoretical Economics Letters, 9, 709-736.

https://doi.org/10.4236/tel.2019.94047

Received: January 12, 2019

Accepted: March 26, 2019

Published: March 29, 2019

Copyright $\odot 2019$ by author(s) and Scientific Research Publishing Inc. This work is licensed under the Creative Commons Attribution International License (CC BY 4.0).

http://creativecommons.org/licenses/by/4.0/

(c) $\underset{\mathrm{EY}}{\mathrm{C}}$ Open Access

\begin{abstract}
Recent literature emphasized purchasing as a strategic function to improve competitiveness, but existing purchasing models lack a comprehensive approach to define the variety of purchasing practices in purchasing strategic categories. This paper assesses purchasing practices' strategic fit with business strategic priorities, providing an in-depth, descriptive assessment of different purchasing construct practices, and proposing a framework to allocate the variety of purchasing practices according to the targeted strategic intent. The model was tested with cluster analysis of structured questionnaire data from industrial firms in Jordan, to develop an empirical taxonomy of purchasing operational practices. The results suggest that purchasing practices can be grouped into three categories (cost, quality, and availability practices) and there is a significant relationship between different possible purchasing practices and varied related strategic intents, which can be utilized to improve business performance. Practical implications are provided for purchasing executives to better understand what practices need to be adopted in order to reduce transaction costs, in support of firms' overall business strategies.
\end{abstract}

\section{Keywords}

Purchasing Categories, Strategic Intent, Cluster Analysis, Factor Analysis

\section{Introduction}

Four types of purchasing categories were developed by the influential matrix of [1], which recommended a key purchasing strategy for each category, focused on 
efficiency for non-critical items, assurance of supply for bottleneck items, competitive bidding for leverage items, and strategic partnership for strategic items [2]. Following this, other studies suggested portfolio models [3] [4] [5] [6] which were quite similar to the Kraljic matrix in essence, but they were criticized for being focused only on a limited set of contingencies [7] [8]. These models suggest only a limited set of purchasing strategies, and are not distinctive enough in terms of the variety of purchasing priorities implemented within the quadrants [5] [7] [9] [10] [11]. For instance, [12] found that the same purchasing priority was implemented in multiple quadrants of the Kraljic's matrix. In addition, [13] reported that firms implement multiple priorities within each quadrant. For example, firms might have purchasing priorities at the overall function level, while at a more micro level they may have them at the purchase category level [7] [14] [15].

These findings reveal that there is a need for alternative and more comprehensive ways of defining the priorities of purchasing categories. There are two main approaches used to define these priorities. The first approach is to state priorities based on practices, which has thus far been the most commonly used approach in purchasing studies [16] [17] [18]. For instance, [16] distinguished between single versus multiple sourcing, while [17] listed 43 purchasing practices that define purchasing strategies, such as competitive bidding, supply base reduction, and early supplier involvement. Furthermore, [19] examined the strategic priorities and tools implemented by European and North American buyers (at the category level) for direct purchases. These examples show that the contingencies identified in current portfolio models do not fully reflect the complexities faced in contemporary businesses, complemented through the consideration of additional dimensions [20].

A second approach is content focus, which describes priorities based on what firms intend to achieve (i.e. their "strategic intent") in the competitive market [21]. This relates to competitive priorities such as cost, quality, delivery, innovation, and sustainability [22] [23]. Strategic intent is what a firm aims to accomplish in the competitive market, based on a set of contingencies which may lead to different practices and processes and impact on performance [24]. The strategic intent allows us to understand "why" certain practices are implemented [24], yet surprisingly this approach is rarely used in purchasing strategy literature [18] [23]. In operations strategy literature, strategic intent is measured using competitive priorities, which successfully predict differences in operations practices adopted by firms [25] [26]. As the operations and purchasing functions of firms are highly interlinked [18] [27] [28], it has been suggested that the same competitive priorities (i.e. cost, quality, delivery, and innovation) are also valid in the purchasing context [23] [29]. Furthermore, the generic competitive objectives selected by the purchasing function represent the "purchasing task"-that is, those capabilities required by the purchasing function to develop and support the business strategy. According to [30], when transferring statements from the manufacturing function to the purchasing function, purchasing choices must be 
congruent with the purchasing task [31], such that the "how" follows the "what", and generic competitive objectives represent a valid instrument for capturing purchasing strategy [18]. In addition, [22] argued that the first step before deciding on certain purchasing priorities is to define purchasing objectives, which must follow from the business competitive priorities.

Accordingly, this study follows the content focus in categorizing the practices, which has seldom been used to analyze purchasing strategy and to assess its alignment with business strategy. The use of content focus in this study to explore the purchasing function is further justified by its facilitation of internal comparisons with other functions. This renders it a useful tool for assessing the degree of strategic fitness (SF), which is an index of the extent to which the firm has "strategic fit" (alignment) in terms of its strategy relative to available internal and external resources and other functions. Furthermore, within the supply chain management field, purchasing alignment is considered to be a desired state that business executives should strive to achieve [32]. In addition, it is recognized that the full value of purchasing systems can only be realized if practices and decisions are aligned with firms' strategic orientations and capabilities [28] [33]. Hence, there is a need to examine the synergies that exist between elements of the internal and external environment and how their overall effect shapes purchasing alignment.

The importance of purchasing SF has been confirmed by empirical studies demonstrating that firms which manage to align their purchase function perceive increased financial and operational performance [34] [35] [36]. Figure 1 shows the predominant model of the strategic planning process that can be used by the purchasing function, based on the theoretical framework provided by [37]. The proposed model implies that SF should be assessed based on decisions, practices, and activities implemented by the investigated function.

Relatively few studies have identified particular purchasing practices and tools to achieve strategic intent, and thus the optimum SF [5] [34] [38]. This study addresses this gap in the literature and develops a taxonomy of purchasing practices clusters based on strategic competitive intents. We define purchasing practices as activities that can only be implemented or acted upon once a supplier has been selected by the firm. Thus, this research empirically analyzes contemporary management practices in purchasing and their relationships with business strategic intent, to assess the degree of business-purchasing SF and their impact on business performance. Specifically, this paper focuses on the following objectives:

1) To develop an overall empirical assessment of purchasing practices in the purchasing function, and cluster these practices.

2) To empirically assess the relationships among the purchasing practices clusters and firms' strategic intent.

3) To assess the degree of SF between business-strategy and purchasing-practices clusters, and their impacts on business performance.

The remainder of this paper is structured as follows. Section 2 presents the 


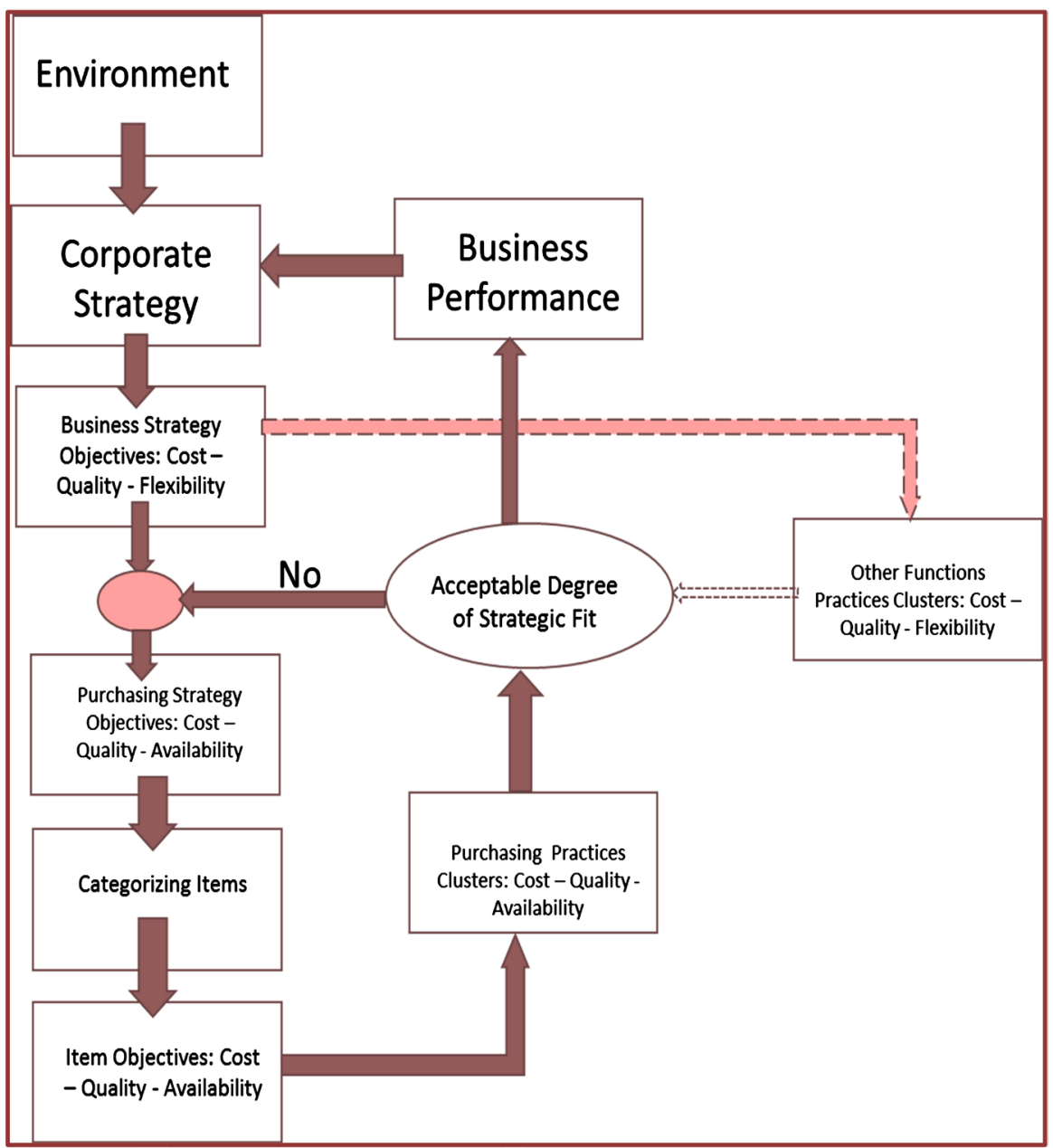

Figure 1. Proposed predominant model of purchasing strategic planning process.

literature review, research framework, and propositions. Section 3 describes the research methodology, including data collection and sample characteristics. Section 4 presents data analysis and results. Discussion and conclusions appear in Section 5, while limitations and directions for future research are presented in Section 6.

\section{Literature Review}

Firms adopt different sets of competitive priorities (objectives pursued in operations to gain competitive advantage) relative to particular internal and external resources, market sector, and strategic targets [26] [39] [40] [41]. These particular combinations of competitive priorities constitute distinct operations strategies that affect practices, processes, and performance [24] [25] [42]. It has been claimed that a target objective for a purchased item is determined by firms' competitive strategic intent [34] [43]. There are several purchasing-related competencies described in the literature, such as competitive strategic intent, but the most traditional list includes cost, quality, and availability [8] [23] [24] [39] [44]. This is closely related to the idea of generic strategies from business 
strategy literature [45]. Accordingly, cost, as a competitive strategic intent, corresponds to cost leadership, while quality and availability correspond to differentiation.

Low cost is an important parameter of firms' strategic intent, but while fundamental market forces determine that firms aim to offer products at a lower cost than competitors, customers evaluate cost in different ways [46] [47] [48]. Some customers may focus simply on the purchase price, including delivery and installation (if applicable), while others may additionally take into account the cost of acquisition, whereby such customers will favor a producer who is able to offer them lower costs in determining specifications, ordering, paying for the purchase, and receiving and storing goods, rather than the mere purchase price in itself [49]. Other customers may further wish to consider the total cost of ownership, including lifetime costs (e.g. operation, maintenance, and disposal) [27] [48] [50]. Most organizations practice cost management and cost reduction according to traditional practices in purchasing [8] [48] [51]. Hence, the focus should be on efficient purchasing, reducing complexity and cost [8] [51]. Accordingly, transaction costs in purchasing processes should be minimized through the implementation of practices such as internal process re-engineering and process automation [8] [52] [53]. For low risk and low value items, purchasing can issue blanket orders (call-off responsibility) to reduce acquisition costs [54]. In addition, many organizations issue purchasing cards for some employees for making small purchases [55], or source suppliers with e-commerce capabilities in order to simplify purchasing transactions within and between organizations [51] [56], which results in businesses reducing their operational costs [57] [58] [59] [60]. In order to reduce the frequency of invoices, many companies seek consolidated billing services from suppliers, delivered electronically, which reduces acquisition costs [61]. Benchmarking has become a common practice in purchasing departments in order to compare how the arrangements offered by a given supplier compare with the practices of the best suppliers in the marketplace, which eventually affects purchase price [62] [63] [64].

On the other hand, a competitive strategic intent of quality for competitive advantage seeks to meet or exceed customer needs [39] [65]. Quality is a multidimensional concept, including functionality, adaptability and flexibility, durability, environmental-friendliness, performance reliability, and image [28] [39] [66]. Quality management practices in purchasing are defined by six constituent quality elements [8] [38] [67] [68] [69] [70]: management support, personnel management, process management, customer relationships, supplier quality management, quality information, product design, and benchmarking. In addition, several studies have offered specific quality management recommendations for purchasing, including teamwork [71] [72], collaborative supplier relationships [8] [73] [74] [75], process improvement [76], and coordination of purchasing with other functional areas [77] [78] [79]. In addition, [80] identified supplier representatives in plants as assisting in two areas of supply chain man- 
agement-purchasing and new product introduction, while [81] suggested that having supplier representatives housed in manufacturing facilities helps reduce response times associated with problems, and mitigates negative effects. Furthermore, utilizing supplier representatives reduces risks and resources, increases knowledge and its sharing, and reduces product-to-market time [82]. Purchasing can capture supplier expertise and innovation by sourcing suppliers who are willing to be involved in the early stages of product development and purchasing operations [66] [83] [84] [85]. The operational practices of purchasing operations are shown in Table 1.

Finally, availability can also have different interpretations, but this paper chooses to define it as the ability to satisfy customer demand for products or services when and where required (flexibility). The concept of availability comprises several dimensions, including lead-time to delivery and continuity of supply. Several organizations have appointed supplier account managers in order to sustain a good relationship with critical suppliers [8] [86]. Furthermore, several authors argue that sharing information (e.g. for demand forecasting) across several supply chain tiers could result in well-informed business decisions for all stakeholders in the extended supply chain [33] [87].

The aforementioned findings suggest a practical scheme, as highlighted in Table 2, which implies that purchasing practices can be categorized according to three broad strategic intents or orientations for deploying purchasing practices: column-wise, row-wise, and cell-wise or (cellular). In the column-wise orientation, firms use multiple purchasing practices for achieving specific strategic intent. For example, firms desiring to improve quality performance may choose to use quality planning and assurance practices for quality. In the row-wise orientation, firms use specific purchasing practices for achieving multiple strategic intents. For instance, value analysis/ engineering can be used for multiple purposes, such as availability, quality improvement, and lower costs. Finally, in the cellular approach, specific purchasing practices are geared towards achieving specific strategic dimensions. For example, firms seeking to improve overall availability performance can deploy a supplier account manager.

The literature review suggests that the cellular approach has not been examined in a comprehensive manner in any single study. Given that there can be a huge number of possible cells, the cellular approach offers little help in terms of reducing the broad array of purchasing practices into a manageable set. Thus, the question becomes whether these purchasing practices are organized in a manner driven by the practice itself (i.e. row-wise), or by the strategic intent behind the purchasing practices (i.e. column-wise). This proposition (as illustrated in Table 2) does not specify item-to-factor(s) correspondence, which would be necessary for the confirmatory approach. Indeed, it is premature to conduct a confirmatory analysis, thus we have termed our expectations as propositions, as opposed to hypotheses.

Our research focus is on whether the split will be row-wise or column-wise, as 
Table 1. Purchasing's operational practices.

\begin{tabular}{l} 
Description \\
\hline Process re-engineering \\
Re-engineering effort should focus on internal and external processes to minimize effort and \\
improve performance. Buying companies can adjust processes to better fit supplier processes.
\end{tabular}

\section{Process automation}

Automate the (already simplified) processes.

Delegating call-off responsibility

Items low risk and low value; purchasing function staff do not add value to daily purchasing operations. Responsibility delegated to end-users.

Purchasing cards

Issue purchasing cards to nominated staff within company.

E-commerce

Set up account with supplier enabling online purchases. Can be affected by intermediary website availability, internet auctions, and high number of transactions with single suppliers.

\section{Consolidated billing}

Reducing frequency of invoicing and costs (time and effort in payments).

Benchmarking against industry norms

Compares arrangements offered by suppliers.

Capture supplier expertise and innovation

Pool company and supplier knowledge and expertise.

Quality planning

Details the processes and procedures used in design and manufacture, along with inspection and testing requirements if quality is a risk factor.

On-site supplier support and training

Developing supplier knowledge and capabilities.

Supplier account manager

Provides company focal point to manage supplier relationships (“good customer”).

Demand forecasting and early phased release of specification information

Used to slot requirements into the supplier's production schedule, reducing the risk of delayed delivery, facilitating more reliable contractual commitments to suppliers.

Strategic Intent

Literature

$$
\begin{aligned}
& \text { Cost of acquisition } \\
& \text { Functionality } \\
& \text { Performance reliability } \\
& \text { Durability } \\
& \text { Lead-time to delivery }
\end{aligned}
$$

Cost of acquisition

[52] [53]

Cost of acquisition

Cost of acquisition

Cost of acquisition

Purchase price

Lead-time to delivery

Cost of acquisition

Purchase price

Total cost of ownership

Functionality

Performance reliability

Durability

Image

Performance reliability

Adaptability and flexibility

Durability

Image

Performance reliability Adaptability and flexibility

Durability

Functionality

Lead-time to delivery

Continuity of supply

[8] [86]

Lead-time to delivery

[80] [82] [87]
[61]

[62] [63] [64]

[67]-[79]

[8] [80] [81]

[82]

[5] [66] [83]

[84]

[58] [59] [60] 
Table 2. Purchasing practices model.

\begin{tabular}{cccc}
\hline Purchasing Practices & \multicolumn{3}{c}{ Strategic Intent } \\
\cline { 2 - 4 } Process re-engineering & Cost & Quality & Availability \\
Process automation & $x$ & $x$ & $x$ \\
Delegating call-off responsibility & $x$ & & \\
Purchasing cards & $x$ & & $x$ \\
E-commerce & $x$ & & \\
Consolidated billing & $x$ & & \\
Benchmarking against industry norms & $x$ & $x$ & $x$ \\
Capture supplier expertise and innovation & $x$ & $x$ & $x$ \\
Quality planning & $x$ & $x$ \\
On-site supplier support and training & & $x$ & $x$ \\
Supplier account manager & & & \\
Demand forecasting and early phased release of & & & \\
specification information & & & \\
\hline
\end{tabular}

shown in Table 2. We suggest that purchasing practices are best grouped around strategic intent. This reflects the pervasive theme in the strategic management literature: that "strategy precedes structure" [88] [89] [90]. If we accept the classic ordering of "strategy and then structure", it follows that purchasing practices seen as the structuring of purchasing should factor analyze with reference to strategic underlying dimensions, rather than along dimensions that describe the type of purchasing initiative. Thus:

Proposition 1: Purchasing practices are clustered according to the strategic intent they are meant to support.

The above proposition suggests that purchasing practices can be clustered into cost, quality, and availability. These should be interpreted as "purchasing practices to support cost reduction intent", "purchasing practices to support quality strategic intent," and so on.

In order to validate the clustering in Proposition 1, it is proposed that these underlying factors relate to strategic intent; in particular, we wish to determine if purchasing practices are related to strategic intent, thus:

Proposition 2: There is a positive relationship between each purchasing practice (e.g., purchasing-cost practice) and measures of strategic intent (e.g. strategic intent of cost reduction).

Based on research on the strategic purchasing-customer satisfaction relationship with regard to total quality management [91], a need was identified to develop a model for assessing strategic alignment, arguing that "purchasing practices should fundamentally stem from and be linked to those [firm] priorities if purchasing is to become strategic" [92]. Accordingly, [27] introduced the term "purchasing integration", which refers to "the integration and alignment of stra- 
tegic purchasing practices and goals with that of the firm"; whereby what the purchasing function does (practices) and what it wants to achieve (goals) have to be coherent and related to the activities and objectives of the firm. Following this concept, [93] and [94] proved that the degree of strategic integration of the purchasing function positively moderates the relationship between purchasing efficacy and business performance; in this regard, [94] noted that "the strategic integration of the purchasing function can be viewed as a good indicator of strategic alignment". Furthermore, [28] also developed a model of the alignment-performance link in purchasing. Both [93] and [28] proved that the strategic alignment between the purchasing strategy and the firm strategy is a mean to raise business performance [95]. Consequently, both studies constitute additional proof of the importance of strategic alignment, as they empirically analyzed the contribution of this relationship to business performance. Following this stream of research, in this paper we propose a framework for assessing SF based on purchasing practices or activities implemented by the function shown in Figure 1. Accordingly, our final proposition is:

Proposition 3: The degree of SF between business-strategy and purchasing-practices clusters has a positive impact on business performance.

From the preceding literature review, it can be observed that:

1) Purchasing practices can exhibit a significant, positive relationship with more than one dimension of strategic intent.

2) Purchasing practices are usually discussed individually. One goal in this research is to determine whether sets or "bundles" of purchasing initiatives (from factor analysis related to Proposition 1) are related to one or more dimensions of strategic intent (Proposition 2).

3) There is a positive relationship between the degree of strategic fitness and its impact on business performance (Proposition 3).

\section{Research Methodology}

Several steps were applied in order to address the study objectives and test the study propositions (Figure 2). First, the preceding literature review discussed purchasing practices and identified the gap in existing literature addressed by this paper. Consequently, a survey questionnaire was developed based on the findings summarized in Table 1, followed by a hierarchical agglomerative clustering method to determine the appropriate number of clusters [96]. Exploratory factor analysis (EFA) using principal component analysis method was then used to extract and identify the practices in each cluster. The study objectives and propositions were then investigated.

\subsection{Sample Characteristics}

This empirical study is based on data gathered from manufacturing companies, most of which represented three general industries: food and beverages $(n=62$ companies, $n=156$ participants), textiles and clothing $(n=73$ companies, $n=$ 


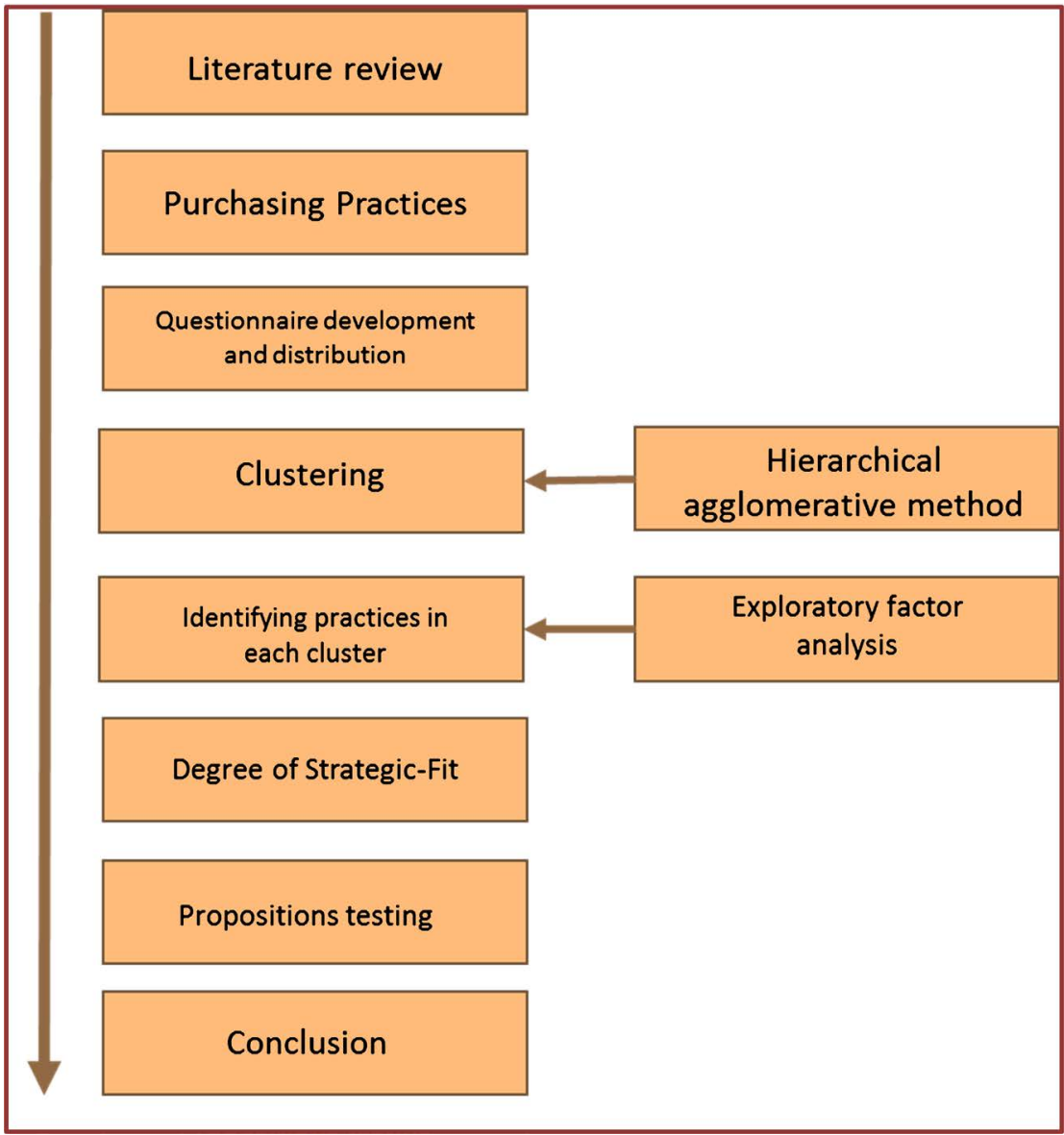

Figure 2. The research procedure.

196 participants), and pharmaceutical and medical supplies ( $\mathrm{n}=55$ companies, $\mathrm{n}=140$ participants). The selection criteria were that the companies should have at least 50 employees, and the majority of their purchases should be made from outside suppliers. The participants included general managers, purchasing managers, and supervisors. Furthermore, these particular industries were chosen because of their significant impact on the Jordanian economy, as they are considered the largest national export industries [97]. Respondents were carefully selected from each industrial company for their knowledge about purchasing and supply processes. The population included purchasing executives, with titles such as Director of Purchasing or Purchasing Manager. In addition, general managers were asked to respond to the survey part related to the strategic intent and business performance of their firm (see Part II of Appendix A).

These high-ranking managerial positions chosen as the respondent group because of their knowledge of the subject matter in the survey instrument, especially pertaining to purchasing practices. This was necessary in order to increase the reliability of the data gathered [98] [99].

\subsection{Methods}

A structured questionnaire was used to collect data pertaining to the research 
objective from the case studies [100]. The unit of analysis for this study was the firm.

Three aspects of strategic intent were measured in this study: cost reduction, quality improvement, and availability. The business performance was measured using financial and market criteria [101] [102] [103], including the growth of sales, the growth of market share, and overall competitive position. Tests for non-response bias were carried out by comparing early respondents (responses received within the first two weeks) and later respondents (responses received within the third week or later) [104]. A t-test of difference was conducted on firm size (employees and sales), and mean responses to each variable, and no statistically significant differences were identified at $\mathrm{p}<0.05$.

The items used to measure the practices were based on the findings from the literature review. If a firm did not use a practice, respondents were asked to circle "Not Used". All items were measured on a five-point Likert scale, ranging from 1 = "extremely low use of practice" to $5=$ "extremely high use of practice". Purchasing employees (e.g. purchasing officers) were asked to respond to these practices and questionnaire items (Appendix A). In addition, senior managers (purchasing managers and/ or general managers) of the respective organizations were asked to respond to the strategic intent and business performance items. The strategic intent and business performance of the firm were also measured using a five-point Likert scale (Appendix A).

Two research assistants provided help with making personal contacts. The key investigators were then able to make personal visits to the surveyed companies between September 2016 and January 2017. As a result, 190 companies from the three targeted industries participated in the study (Table 3). Respondents from each firm were asked to provide a five-point rating of their firm's relative strategic intent importance, from $1=$ "least important" to $5=$ "extremely important".

\section{Data Analysis and Discussion}

\subsection{Clustering Purchasing Practices}

Before conducting cluster analysis, Kruskal-Wallis test was applied in order to check whether there were any significant differences between the median scores of the three types of industry. Non-parametric Kruskal-Wallis tests on 40 items revealed no significant differences ( $\alpha<=0.05$ ) between different types of industry among the investigated firms. Thus, the groups of firms were treated as one sample for further analysis. All firms were manufacturing-based companies with different product lines.

Table 3. Sectors of surveyed companies.

\begin{tabular}{ccc}
\hline \multicolumn{2}{c}{ Type of Industry } \\
\hline Food \& beverages & Pharmaceutical \& medical supplies & Textiles \& clothing \\
\hline 62 & 55 & 73 \\
\hline
\end{tabular}


Cluster analysis was used to classify a set of objects into two or more groups based on similarity [105]. Three clusters are appropriate to segment practices according to the hierarchical agglomerative clustering method used [96]. The Euclidean distances among the three clusters (Table 4) provided insights into purchasing practices implemented for each cluster (whereby larger values represent greater dissimilarity between clusters). Table 5 shows that the majority of companies in Clusters 1, 2, and 3 specialized in food and beverages, pharmaceutical and medical supplies, and textiles and clothing, respectively.

\subsection{Identification of Purchasing Practices in Each Cluster (Proposition 1)}

As stated earlier in the discussion of the conceptual model in Table 2, the literature is not clear regarding whether the deployment of purchasing practices is competitive priority-holistic, raising the question of whether purchasing practices are grouped according to the strategic intent they are meant to support. Factor analysis was performed to test the validity of measures used in measuring the practices. The Kaiser-Meyer-Olkin measure of sampling adequacy is 0.8 (above the recommended level of 0.6), and Bartlett's test of sphericity is significant $(\mathrm{p}<0.01)$. The 27 purchasing items were subject to principal components factor analysis with varimax rotation. The factor analysis revealed a stable threefactor solution, with each of the factors having eigenvalues exceeding one. The cumulative percentage of total variance explained due to these three factors was $78.6 \%$.

Table 6 presents the results of the factor analysis. It can be seen that there was a high degree of convergence within each factor (the lowest factor loading within a factor was 0.620). In addition, there was a high degree of divergence across

Table 4. Euclidean distances between clusters.

\begin{tabular}{cccc}
\hline & \multicolumn{3}{c}{ Euclidean Distances } \\
\cline { 2 - 4 } Cluster \# & 1 & 2 & 3 \\
\hline 1 & 0.00 & 0.76 & 0.85 \\
2 & 0.76 & 0.00 & 1.21 \\
3 & 0.85 & 1.21 & 0.00 \\
\hline
\end{tabular}

Table 5. Company types by clusters.

\begin{tabular}{ccccccc}
\hline \multirow{2}{*}{ Company Type } & \multicolumn{2}{c}{ Cluster 1} & \multicolumn{2}{c}{ Cluster 2} & \multicolumn{2}{c}{ Cluster 3 } \\
\cline { 2 - 6 } & $\%$ & No. & $\%$ & No. & $\%$ & No. \\
\hline $\begin{array}{c}\text { Food \& beverages } \\
\text { Pharmaceutical \& }\end{array}$ & 81.25 & 52 & 10.34 & 6 & 5.88 & 4 \\
medical supplies & 6.25 & 4 & 84.48 & 49 & 2.94 & 2 \\
$\begin{array}{c}\text { Textiles \& clothing } \\
\text { Total }\end{array}$ & 12.5 & 8 & 5.17 & 3 & 91.17 & 62 \\
\hline
\end{tabular}


Table 6. Means, standard deviations, Cronbach's alpha coefficients, and rotated factor loadings for three purchasing factors.

\begin{tabular}{|c|c|c|c|c|c|c|}
\hline $\begin{array}{l}\text { Construct/ } \\
\text { item }\end{array}$ & Mean & SD & $\begin{array}{l}\text { Cronbach's } \\
\text { alpha }\end{array}$ & $\begin{array}{l}\text { Cluster } 1 \\
\text { (Cost) }\end{array}$ & $\begin{array}{l}\text { Cluster } 2 \\
\text { (Quality) }\end{array}$ & $\begin{array}{c}\text { Cluster } 3 \\
\text { (Availability) }\end{array}$ \\
\hline CP: Cost Practices & 3.2742 & & 0.904 & & & \\
\hline $\mathrm{CP} 1$ & 3.9348 & 1.23652 & 0.845 & 0.756 & 0.109 & -0.006 \\
\hline $\mathrm{CP} 2$ & 3.4783 & 1.47180 & 0.755 & 0.851 & 0.067 & 0.021 \\
\hline $\mathrm{CP} 3$ & 3.5652 & 1.42442 & 0.653 & 0.693 & -0.040 & 0.015 \\
\hline $\mathrm{CP} 4$ & 3.2609 & 1.65240 & 0.881 & 0.647 & 0.037 & 0.213 \\
\hline CP5 & 2.3913 & 1.55604 & 0.891 & 0.648 & 0.055 & 0.001 \\
\hline CP6 & 2.5217 & 1.36201 & 0.733 & 0.883 & 0.0143 & -0.052 \\
\hline CP7 & 2.5652 & 1.48552 & 0.866 & 0.687 & 0.026 & 0.102 \\
\hline $\mathrm{CP} 8$ & 2.4783 & 1.58800 & 0.821 & 0.651 & 0.132 & 0.154 \\
\hline CP9 & 2.6304 & 1.65138 & 0.666 & 0.759 & 0.003 & 0.204 \\
\hline $\mathrm{CP} 10$ & 2.9130 & 1.58921 & 0.823 & 0.634 & 0.249 & 0.008 \\
\hline $\mathrm{CP} 11$ & 4.2609 & 1.21901 & 0.799 & 0.749 & 0.079 & -0.069 \\
\hline CP12 & 3.5652 & 1.51514 & 0.855 & 0.845 & 0.009 & 0.091 \\
\hline $\mathrm{CP} 13$ & 3.7826 & 1.47442 & 0.869 & 0.768 & 0.188 & 0.270 \\
\hline QP: Quality Practices & 3.7891 & & 0.888 & & 0.774 & \\
\hline QP1 & 4.1522 & 1.28179 & 0.721 & -0.009 & 0.824 & -0.015 \\
\hline QP2 & 3.9348 & 1.27196 & 0.801 & -0.058 & 0.835 & 0.206 \\
\hline QP3 & 4.0000 & 1.19257 & 0.811 & 0.188 & 0.852 & -0.085 \\
\hline QP4 & 3.7174 & 1.40891 & 0.799 & 0.237 & 0.666 & 0.139 \\
\hline QP5 & 3.7826 & 1.34846 & 0.761 & 0.091 & 0.648 & 0.178 \\
\hline QP6 & 3.6304 & 1.40410 & 0.777 & 0.014 & 0.722 & 0.002 \\
\hline QP7 & 3.5870 & 1.42324 & 0.769 & 0.009 & 0.620 & -0.023 \\
\hline QP8 & 3.9783 & 1.34146 & 0.859 & 0.238 & 0.711 & 0.273 \\
\hline QP9 & 3.9348 & 1.35650 & 0.719 & -0.101 & 0.839 & 0.049 \\
\hline QP10 & 3.1739 & 1.53918 & 0.694 & -0.002 & 0.701 & 0.209 \\
\hline $\begin{array}{c}\text { AP: Availability Prac- } \\
\text { tices }\end{array}$ & 3.7663 & & 0.866 & & & \\
\hline AP1 & 3.9565 & 1.33261 & 0.728 & 0.257 & 0.086 & 0.861 \\
\hline AP2 & 3.4348 & 1.52974 & 0.729 & 0.006 & 0.077 & 0.798 \\
\hline AP3 & 3.8913 & 1.46406 & 0.806 & 0.093 & -0.098 & 0.823 \\
\hline AP4 & 3.7826 & 1.38103 & 0.801 & -0.087 & -0.018 & 0.715 \\
\hline \multicolumn{4}{|c|}{ Eigenvalue } & 5.822 & 4.121 & 2.431 \\
\hline \multicolumn{4}{|c|}{ Percentage of variance explained } & $34.0 \%$ & $25.5 \%$ & $19.1 \%$ \\
\hline \multicolumn{4}{|c|}{ Cumulative percentage of total variance explained } & $34.0 \%$ & $59.5 \%$ & $78.6 \%$ \\
\hline
\end{tabular}


factors, as indicated by the lack of cross-loading of any item on more than one factor. Clearly, the nature of the items that load on each factor suggests three factors, named purchasing-cost, purchasing-quality, and purchasing-availability practices.

The items forming each of the purchasing factors were then tested for internal consistency using Cronbach's alpha [106]. Reliability refers to the ability to yield consistent results [106]. The reliability analysis was conducted by calculating the Cronbach's alpha for each scale. Table 6 shows that the scales for each of the purchasing factors were internally consistent and the constructs were reliable, with Cronbach's alpha coefficient values ranging from 0.653 to 0.904 . From the interpretation of results shown in Table 6, the studied companies fall in three major clusters:

Cluster 1: This cluster contains 52 out of 62 surveyed companies in the food and beverages industry. The opinions of executives and managers in the food industry emphasize indicators of cost in their strategic intent [107]. Accordingly, internal processes must reduce costs to support such strategic intent. Cluster 1 companies use purchasing cost practices.

Cluster 2: This cluster contains 49 out of 55 surveyed companies in the pharmaceutical and medical supplies industry. Quality management is critical to pharmaceutical companies and their stakeholders [108]. Accordingly, all functions must set their own objectives to support the strategic intent of quality. Cluster 2 companies use purchasing quality practices.

Cluster 3: This cluster contains 62 out of 73 surveyed companies, in the textiles and clothing industry. Retailers in this sector require rapid replenishment of products [109], and shipments need to meet strict requirements in terms of delivery times, order completeness, and accuracy [8]. Cluster 3 companies use purchasing availability practices.

Overall, the analyses indicated that the constructs were one-dimensional and reliable, and thus the factor scored items were taken as the units for further analyses for testing Proposition 2, using factor analysis.

\subsection{Purchasing Factors and Strategic Priorities (Proposition 2)}

In order to seek richer patterns and to establish criterion validity, three external variables were chosen for linking with cluster solutions. The reviewed literature strongly supports practices within functions being implemented in order to support the strategic intent [24] [25] [42]. Our study chose three strategic intents organizations might pursue, comprising cost, quality, and availability. The study measured these intents subjectively on a five-point Likert scale. Statistical testing on relationships between these variables (exogenous variables, not used in clustering) and cluster solutions were tested. F-test results show statistical significance for these variables, as shown in Table 7. F-test results show that three clusters (cost, quality, and availability) significantly differ on three exogenous variables. This analysis establishes the criterion validity of the three clusters solu- 
tion.

The correlations and p-values of the three purchasing factors with the three strategic intent items are presented in Table 8. For cost, quality, and availability, each purchasing factor consistently related to the intent in its respective strategic dimension. For example, purchasing-cost was significantly related to strategic intent of cost $(\mathrm{p}=0.000)$. Two purchasing practices were related to multiple strategic intents. Purchasing-cost practice was a significant predictor of availability and cost priority. This means that some purchasing practices are utilized to achieve multiple strategic intents, as suggested in Table 4 . Based on the results of correlations, we can conclude that (overall) Proposition 2 is supported.

\subsection{Strategic Fitness Scores}

A moderation approach suggested by [110] was used to measure the SF scores. SF (alignment) is measured by multiplying the ratings of each of the strategic priority items [111]. As a result, a high rating for business strategy and a high rating of purchasing cluster practice results in a high SF (alignment) measure, and vice-versa. For example, for each company and each strategy area, the rating for a business strategy is multiplied by the rating of its respective purchasing cluster practice. An ideally aligned firm would score 25 on each strategic intent, as shown in Table 9.

The overall strategic alignment is calculated by finding the square root of multiplying total sub-aligned strategic intent. A totally aligned firm would score

Table 7. Distribution of respondent companies between three clusters.

\begin{tabular}{cccc}
\hline & \multicolumn{3}{c}{ Strategic Intent-Overall Mean Score } \\
\cline { 2 - 4 } & Cost & Quality & Availability \\
\hline Cluster 1 & 4.51 & 2.34 & 2.77 \\
Cluster 2 & 3.65 & 4.21 & 3.02 \\
Cluster 3 & 2.34 & 3.21 & 4.34 \\
F-value & 23.45 & 15.67 & 12.56 \\
Significance level & 0.02 & 0.06 & 0.07 \\
\hline
\end{tabular}

Table 8. Correlations of purchasing factors and strategic intent.

\begin{tabular}{|c|c|c|c|c|}
\hline \multirow{2}{*}{ Variable } & \multirow{2}{*}{ Correlation } & \multicolumn{3}{|c|}{ Practices } \\
\hline & & Purchasing-Cost & Purchasing-Quality & Purchasing-Availability \\
\hline \multirow{2}{*}{ Cost-Intent } & $r=$ & 0.678 & 0.055 & 0.561 \\
\hline & $\mathrm{p}=$ & 0.000 & 0.765 & 0.051 \\
\hline \multirow{2}{*}{ Quality-Intent } & $r=$ & 0.221 & 0.844 & 0.005 \\
\hline & $\mathrm{p}=$ & 0.102 & 0.000 & 0.871 \\
\hline \multirow{2}{*}{ Availability-Intent } & $r=$ & 0.522 & 0.023 & 0.425 \\
\hline & $\mathrm{p}=$ & 0.061 & 0.867 & 0.033 \\
\hline
\end{tabular}


125 for overall strategic alignment. The mean product for business and purchasing practice SF is shown in Table 9. The scores for overall SF ranged from 31 to 64 , with a mean of 48.81 and a standard deviation of 16.13 . This high variability indicated wide ranges of different situations covered in the sample. It also showed that respondents used the full range of possible responses on the questionnaire. However, a mean of 48.81 is considered very low compared to the possible score of 125. The example in Appendix B illustrates the process of calculating the SF scores.

\subsection{Strategic Fit and Business Performance}

To test Proposition 3, one-way analysis of variance (ANOVA) was used to test the relationship between SF of business-purchasing and the individual and overall measures of business performance. For this analysis, the sample with complete SF data was split into three groups of firms based on their alignment (moderation) scores. For ease of reference, these three groups of firms are referred to as "high", "medium", and "low" alignment. The first and third quartiles were used in splitting the sample for each SF component, and the ANOVA compared the mean performance scores for the three groups in each SF component. The means and $\mathrm{F}$ values are reported in Table 10. The reported $\mathrm{F}$ values were all significant at $\alpha \leq 0.05$. Performance was consistently highest in highly aligned groups of firms. In addition, the data shows that firms which achieve higher levels of alignment have higher levels of performance. The results shown in Table 10 support Proposition 3, demonstrating that firms which achieve high SF among their strategies (business and purchasing) are more likely to perform better than those which do not.

Table 9. Strategic fit descriptive statistics (mean and standard deviation, $\mathrm{n}=190$ ).

\begin{tabular}{ccccc}
\hline Strategic Fit & Practice-Cluster & Mean & Standard Deviation & Ideal score \\
\hline \multirow{2}{*}{ Business-Purchasing Practices } & Quality & 15.73 & 6.21 & 25 \\
& Cost & 11.21 & 5.75 & 25 \\
Strategic Fit & Availability & 13.51 & 7.29 & 25 \\
& Overall & 48.81 & 16.13 & 125 \\
\hline
\end{tabular}

Table 10. One-way ANOVA between strategic fit (components), groups, and business performance (moderation) $(\mathrm{n}=190)$.

\begin{tabular}{ccccccc}
\hline \multirow{2}{*}{\begin{tabular}{c} 
Business-Performance \\
\cline { 2 - 7 }
\end{tabular}} & Low (82) & Medium (71) & High (37) & F ratio F prob. Significance \\
\cline { 2 - 7 } The growth of market & 2.6531 & 3.0132 & 3.5252 & 5.87 & 0.015 & Yes \\
The growth of sales & 2.6202 & 3.1034 & 3.7012 & 7.31 & 0.004 & Yes \\
Overall competitive position & 2.3221 & 3.0745 & 3.6522 & 12.01 & 0.014 & Yes \\
Overall-business performance & 2.4123 & 3.0208 & 3.6111 & 16.73 & 0.000 & Yes \\
\hline
\end{tabular}




\section{Discussion and Conclusions}

SF studies in purchasing focused on the functional level to test the alignment of this function with business strategy. This study suggests that SF should be analyzed on the practices level rather than on the functional level with regard to purchasing. Purchasing models in extant literature lack a comprehensive approach to define the variety of purchasing practices implemented in each purchasing strategic category. Thus, the aim of this paper was to develop and provide an overall empirical assessment of the different practices in the purchasing construct. A conceptual model was proposed and tested to achieve the objective. This study adds to the extant literature at the interface of purchasing and business strategy, and it is one of the first studies to develop a comprehensive conceptualization of purchasing practices.

A detailed review of the literature identified cost, quality, and availability constructs of practices in purchasing and corresponding measurement instruments were consequently developed. The subsequent results of scale refinement and validation procedures indicated that the scales used were valid and reliable [99]. From a managerial perspective, the instrument developed provides purchasing managers with the main constituents of practices in the purchasing system, as well as with the specific initiatives to be implemented in each major action program. For example, a business strategy focusing on cost can be achieved by setting cost as the most important goal at the purchasing functional level. Consequently, Proposition 1 can be used as a guide for purchasing managers to adopt a variety of purchasing-cost practices in order to attain the goal.

The findings suggest that there is a significant relationship between the different purchasing practices studied and their related strategic priorities, thus SF could be achieved, which positively affects business performance. Hence, we conclude that some purchasing practices can be utilized to achieve multiple strategic priorities. For instance, the results showed that purchasing-cost practices could be utilized to achieve multiple strategic priorities, as posited by Proposition 2. Also, the study investigated the relationship between business-purchasing SF and business performance, and the results affirmed Proposition 3.

The main significance of this research is that it provides insights for purchasing executives so that they can better understand what kind of practices need to be adopted in order to support firms' overall business strategy. Confronting intense competition in the modern marketplace requires that purchasing and supply managers regularly evaluate their operational practices in a way that fits with the target strategic priorities [24]. Firms should consider appropriate categories for defining their purchasing category strategies. Hence, our study contributes to the theoretical debate on purchasing and strategy, and also provides a rich, in-depth description explanation, at the operational level, of how purchasing managers should employ the different purchasing practices for improved competitive advantage. 


\section{Limitations and Future Research}

As with all research, this study suffers from some limitations. The first limitation is that the population consisted of firms from a single country. Therefore, an extension of this research could include testing the proposed conceptual model from firms in other countries. The second limitation is that data were only gathered from manufacturers, thus the results might be generalizable only to the population of firms who have similar characteristics to Jordanian industrial companies. The third limitation is that the performance results of organizations are the results of gestation time; this study used a cross-sectional design, which by nature does not capture gestation time and longitudinal dynamics and impacts. Therefore, given the exploratory nature of this research, we are cautious in our interpretation of the results, from which we extract the need for further research that examines the role of institutional factors in purchasing decision making over time. However, this study opens up avenues for future researchers. Capturing the perspectives of different populations and settings may lead to different conclusions according to the context of the study [44] [99].

Hence, future studies may use the proposed model in other countries or contexts to enhance the generalizability of the findings. Furthermore, the proposed model could be used to measure SF among other functions in the organization, and consequently assess the total SF of an organization. Furthermore, we recommend that future researchers conduct industry-focused studies to capture the concealed behavior and practices of purchasing managers in different contexts, and from the perspective of other members throughout the supply chain.

\section{Conflicts of Interest}

The authors declare no conflicts of interest regarding the publication of this paper.

\section{References}

[1] Kraljic, P. (1983) Purchasing Must Become Supply Management. Harvard Business Review, 61, 109-117.

[2] Ginsberg, A. and Venkatraman, N. (1985) Contingency Perspectives of Organizational Strategy: A Critical Review of the Empirical Research. Academy of Management Review, 10, 421-434. https://doi.org/10.5465/amr.1985.4278950

[3] Olsen, R. and Ellram, L. (1997) Buyer-Supplier Relationships: Alternative Research Approaches. European Journal of Purchasing and Supply Management, 4, 221-231. https://doi.org/10.1016/S0969-7012(97)00022-1

[4] Bensaou, M. (1999) Portfolios of Buyer-Supplier Relationships. Sloan Management Review, 40, 35-44.

[5] Hesping, F.H. and Schiele, H. (2016) Matching Tactical Sourcing Levers with the Kraljič Matrix: Empirical Evidence on Purchasing Portfolios. International Journal of Production Economics, 177, 101-117. https://doi.org/10.1016/j.ijpe.2016.04.011

[6] Vitasek, K. (2016) Strategic Sourcing Business Models. Strategic Outsourcing. An International Journal, 9, 126-138. https://doi.org/10.1108/SO-02-2016-0003 
[7] Luzzini, D., Caniato, F., Ronchi, S. and Spina, G. (2012) A Transaction Costs Approach to Purchasing Portfolio Management. International Journal of Operations and Production Management, 32, 1015-1042. https://doi.org/10.1108/01443571211265684

[8] Gangurde, S.R. and Chavan, A.A. (2016) Benchmarking of Purchasing Practices Using Kraljic Approach. Benchmarking: An International Journal, 23, 1751-1779. https://doi.org/10.1108/BIJ-01-2015-0011

[9] Caniëls, M. and Gelderman, C. (2007) Power and Interdependence in Buyer Supplier Relationships: A Purchasing Portfolio Approach. Industrial Marketing Management, 36, 219-229. https://doi.org/10.1016/j.indmarman.2005.08.012

[10] Krause, D.R., Vachon, S. and Klassen, R.D. (2009) Special Topic Forum on Sustainable Supply Chain Management: Introduction and Reflections on the Role of Purchasing Management. Journal of Supply Chain Management, 45, 18-25. https://doi.org/10.1111/j.1745-493X.2009.03173.x

[11] Pagell, M., Wu, Z. and Wasserman, M.E. (2010) Thinking Differently About Purchasing Portfolios: An Assessment of Sustainable Sourcing. Journal of Supply Chain Management, 46, 57-73. https://doi.org/10.1111/j.1745-493X.2009.03186.X

[12] Faes, W. and Matthyssens, P. (2009) Insights into the Process of Changing Sourcing Strategies. Journal of Business and Industrial Marketing, 24, 245-255. https://doi.org/10.1108/08858620910939796

[13] Gelderman, C.J. and van Weele, A.J. (2005) Purchasing Portfolio Models: A Critique and Update. Journal of Supply Chain Management, 41, 19-28. https://doi.org/10.1111/j.1055-6001.2005.04103003.x

[14] Trautmann, G., Turkulainen, V., Hartmann, E. and Bals, L. (2009) Integration in the Global Sourcing Organization: An Information Processing Perspective. Journal of Supply Chain Management, 45, 57-74. https://doi.org/10.1111/j.1745-493X.2009.03163.x

[15] Terpend, R., Krause, D.R. and Dooley, K.J. (2011) Managing Buyer-Supplier Relationships: Empirical Patterns of Strategy Formulation in Industrial Purchasing. Journal of Supply Chain Management, 47, 73-94. https://doi.org/10.1111/j.1745-493X.2010.03215.x

[16] Treleven, M. and Schweikhart, S.B. (1988) A Risk/Benefit Analysis of Sourcing Strategies: Single versus Multiple Sourcing. Journal of Operations Management, 7, 93-114. https://doi.org/10.1016/0272-6963(81)90007-3

[17] Birou, L.M., Fawcett, S.E. and Magnan, G.M. (1998) The Product Life Cycle: A Tool for Functional Strategic Alignment. International Journal of Purchasing and Materials Management, 34, 37-51. https://doi.org/10.1111/j.1745-493X.1998.tb00047.x

[18] González-Benito, J. (2010) Supply Strategy and Business Performance: An Analysis Based on the Relative Importance Assigned to Generic Competitive Objectives. International Journal of Operations and Production Management, 30, 774-797. https://doi.org/10.1108/01443571011068162

[19] Karjalainen, K. and Salmi, A. (2013) Continental Differences in Purchasing Strategies and Tools. International Business Review, 22, 112-125. https://doi.org/10.1016/j.ibusrev.2012.02.008

[20] Mahapatra, S.K., Narasimhan, R., Barbieri, P. (2010) Strategic Interdependence, Governance Effectiveness and Supplier Performance: A Dyadic Case Study Investigation and Theory Development. Journal of Operations Management, 28, 537-552. https://doi.org/10.1016/j.jom.2010.04.001

[21] Hamel, G. and Prahalad, C.K. (1989) Strategic Intent. Harvard Business Review, 67, 
63-76.

[22] Watts, C.A., Kim, K.Y. and Hahn, C.K. (1995) Linking Purchasing to Corporate Competitive Strategy. International Journal of Purchasing and Materials Management, 31, 2-8. https://doi.org/10.1111/j.1745-493X.1995.tb00197.x

[23] Krause, D.R., Pagell, M. and Curkovic, S. (2001) Toward a Measure of Competitive Priorities for Purchasing. Journal of Operations Management, 19, 497-512. https://doi.org/10.1016/S0272-6963(01)00047-X

[24] Kern, D., Moser, R., Sundaresan, N. and Hartmann, E. (2011) Purchasing Competence: A Stakeholder-Based Framework for Chief Purchasing Officer, Journal of Business Logistics, 32, 122-138

[25] Kathuria, R. (2000) Competitive Priorities and Managerial Performance: A Taxonomy of Small Manufacturers. Journal of Operations Management, 18, 627-641. https://doi.org/10.1016/S0272-6963(00)00042-5

[26] Boyer, K.K. and Lewis, M.W. (2002) Competitive Priorities: Investigating the Need for Trade-Offs in Operations Strategy. Production and Operations Management, 11, 9-20. https://doi.org/10.1111/j.1937-5956.2002.tb00181.x

[27] Narasimhan, R. and Das, A. (2001) The Impact of Purchasing Integration and Practices on Manufacturing Performance. Journal of Operations Management, 19, 593 609. https://doi.org/10.1016/S0272-6963(01)00055-9

[28] Baier, C., Hartmann, E. and Moser, R. (2008) Strategic Alignment and Purchasing Efficacy: An Exploratory Analysis of their Impact on Financial Performance. Journal of Supply Chain Management, 44, 36-52.

https://doi.org/10.1111/j.1745-493X.2008.00071.x

[29] Pagell, M. and Krause, D.R. (2002) Strategic Consensus in the Internal Supply Chain: Exploring the Manufacturing-Purchasing Link. International Journal of Production Research, 40, 3075-3092. https://doi.org/10.1080/00207540210136540

[30] Miller, J.G. and Roth, A.V. (1994) A Taxonomy of Manufacturing Strategy. Management Science, 40, 285-304. https://doi.org/10.1287/mnsc.40.3.285

[31] Martín-Peña, M.L. and Díaz-Garrido, E. (2008) A Taxonomy of Manufacturing Strategies in Spanish Companies. International Journal of Operations and Production Management, 28, 455-477. https://doi.org/10.1108/01443570810867204

[32] Wong, C., Skipworth, H., Godsell, J. and Achimugu, N. (2012) Towards a Theory of Supply Chain Alignment Enablers: A Systematic Literature Review. Supply Chain Management: An International Journal, 17, 419-437. https://doi.org/10.1108/13598541211246567

[33] Ali, I. and Shukran, K. (2016) Managing Supply Chain Risks and Vulnerabilities through Collaboration: Present and Future Scope. The Journal of Developing Areas, 50, 335-342. https://doi.org/10.1353/jda.2016.0027

[34] Rodríguez-Escobar, J. and González-Benito, J. (2017) The Effect of Strategic Alignment on Purchasing Management. Management Research Review, 40, 1175-1200,

[35] Cousins, P.D. (2005) The Alignment of Appropriate Firm and Supply Strategies for Competitive Advantage. International Journal of Operations and Production Management, 25, 403-428. https://doi.org/10.1108/01443570510593120

[36] Mikalef, P., Pateli, A., Batenburg, R. and van de Wetering, R. (2014) Business Alignment in the Procurement Domain: A Study of Antecedents and Determinants of Supply Chain Performance. International Journal of Information Systems and Project Management, 2, 43-59.

[37] Hayes, R.H. and Wheelwright, S.C. (1984) Restoring Our Competitive Edge: Com- 
peting through Manufacturing. Wiley, New York, NY.

[38] Sánchez-Rodríguez, C. and Martinez-Lorente, A.R. (2004) Quality Management Practices in the Purchasing Function. International Journal of Operations and Production Management, 24, 666-687. https://doi.org/10.1108/01443570410541984

[39] Sánchez-Rodríguez, C., Hemsworth, D. and Martinez-Lorente, A.R. (2004) Quality Management Practices in Purchasing and Its Effect on Purchasing's Operational Performance and Internal Customer Satisfaction. International Journal of Logistics. Research and Applications, 7, 325-344. https://doi.org/10.1080/13675560410001716214

[40] Kathuria, R., Porth, S., Kathuria, N. N. and Kohli, T.K. (2010) Competitive Priorities and Strategic Consensus in Emerging Economies: Evidence from India. International Journal of Operations and Production Management, 30, 879-896. https://doi.org/10.1108/01443571011068207

[41] Koubaa, Y. (2016) An Empirical Illustration of the Transformation Process of Purchasing: An Application of the System Dynamic Modelling Approach. The International Journal of Logistics Management, 27, 167-187. https://doi.org/10.1108/IJLM-06-2012-0041

[42] Christiansen, T., Berry, W.L., Bruun, P. and Ward, P. (2003) A Mapping of Competitive Priorities, Manufacturing Practices and Operational Performance in Groups of Danish Manufacturing Companies. International Journal of Operations and Production Management, 23, 1163-1183. https://doi.org/10.1108/01443570310496616

[43] Lee, D.M. and Drake, P.R. (2010) A Portfolio Model for Component Purchasing Strategy and the Case Study of Two South Korean Elevator Manufacturers. International Journal of Production Research, 48, 6651-6682. https://doi.org/10.1080/00207540902897780

[44] Miocevic, D. (2011) Organizational Buying Effectiveness in Supply Chain Context: Conceptualization and Empirical Assessment. Journal of Purchasing and Supply Management, 17, 246-255. https://doi.org/10.1016/j.pursup.2011.09.001

[45] Porter, M.E. (1980) Competitive Strategy. Free Press, New York, NY.

[46] Carter, J.R. and Narasimhan, R. (1995) Purchasing and Supply Management: Future Directions and Trends. International Journal of Purchasing and Materials Management, 32, 2-12. https://doi.org/10.1111/j.1745-493X.1996.tb00225.x

[47] Carter, J.R., Smeltzer, L. and Narasimhan, R. (1998) The Role of Buyer and Supplier Relationships in Integrating TQM through the Supply Chain. European Journal of Purchasing and Supply Management, 4, 223-234. https://doi.org/10.1016/S0969-7012(98)00013-6

[48] Zsidisin, G.A., Ellram, L.M. and Ogden, J.A. (2011) The Relationship between Purchasing and Supply Management's Perceived Value and Participation in Strategic Supplier Cost Management Activities. Journal of Business Logistics, 24, 129-154. https://doi.org/10.1002/j.2158-1592.2003.tb00049.x

[49] Nellore, R. and Soderquist, K. (2000) Portfolio Approaches to Procurement: Analysing the Missing Link to Specifications. Long Range Planning, 33, 245-267. https://doi.org/10.1016/S0024-6301(00)00027-3

[50] David, J.S., Hwang, Y., Pei, B.K. and Reneau, J.H. (2002) The Performance Effects of Congruence between Product Competitive Strategies and Purchasing Management Design. Management Science, 48, 866-885. https://doi.org/10.1287/mnsc.48.7.866.2819

[51] Van Weele, A.J. (2010) Purchasing and Supply Chain Management: Analysis, Strat- 
egy, Planning and Practice. Cengage Learning, Boston, MA.

[52] Rantala, L. and Hilmola, O.P. (2005) From Manual to Automated Purchasing. Industrial Management and Data Systems, 105, 1053-1069. https://doi.org/10.1108/02635570510624446

[53] Craighead, C.W., Hult, G.T.M. and Ketchen, Jr. D.J. (2009) The Effects of Innovation-Cost Strategy, Knowledge and Action in the Supply Chain on Firm Performance. Journal of Operations Management, 27, 405-421. https://doi.org/10.1016/j.jom.2009.01.002

[54] Zenz, G. and Thompson, G.H. (1994) Purchasing and the Management of Materials. 7th Edition, Wiley and Sons, New York, NY.

[55] Sriram, V. and Stump, R. (2004) Information Technology Investments in Purchasing: An Empirical Investigation of Communications, Relationship and Performance Outcomes. Omega, 32, 41-55. https://doi.org/10.1016/j.omega.2003.09.008

[56] Timmers, P. (1999) Electronic Commerce: Strategies and Models for Businessto-Business Trading. Wiley, New York, NY.

[57] Mantel, B. (2001) E-Money and E-Commerce: Two Alternative Views of Future Innovations. Chicago Fed Letter, 163, 1-4.

[58] Moore, M. (2001) The Challenges and Opportunities of E-Commerce. Business Credit, 103, 52-53.

[59] Carabello, L. (2001) E-Procurement Can Reduce Expenses. Healthcare Financial Management, 55, 82-83.

[60] Osmonbekov, T., Bello, D.C. and Gilliland, D.I. (2009) The Impact of E-Business Infusion on Channel Coordination, Conflict and Reseller Performance. Industrial Marketing Management, 38, 778-784. https://doi.org/10.1016/j.indmarman.2008.03.005

[61] Vincent, V. Folorunso, O. and Akinde, A. (2009) On Consolidation Model in E-Bill Presentment and Payment. Information Management and Computer Security, 17, 234-247 https://doi.org/10.1108/09685220910978121

[62] Carr, A.S. and Smeltzer, L.R. (2000) An Empirical Study of the Relationships Among Purchasing Skills and Strategic Purchasing, Financial Performance and Supplier Responsiveness. Journal of Supply Chain Management, 36, 40-54. https://doi.org/10.1111/j.1745-493X.2000.tb00250.x

[63] Leenders, M.L., Fearon, H.E., Flynn, A.E. and Johnson, P.F. (2002) Purchasing and Supply Management. McGraw-Hill, New York, NY.

[64] Current, J.R. and Weber, C.A. (2003) Purchaser-Originated Benchmarking: PROBING. Benchmarking: An International Journal, 10, 431-444. https://doi.org/10.1108/14635770310495483

[65] David, A.G. (1987) Competing on the Eight Dimensions of Quality. Harvard Business Review, 65, 101-109.

[66] Primo, M. and Amundson, S. (2002) An Exploratory Study of the Effects of Supplier Relationships on New Product Development Outcomes. Journal of Operations Management, 20, 33-52. https://doi.org/10.1016/S0272-6963(01)00080-8

[67] Saraph, J.V., Benson, P.B. and Schroeder, R.G. (1989) An Instrument for Measuring the Critical Factors of Quality Management. Decision Sciences, 20, 810-829. https://doi.org/10.1111/j.1540-5915.1989.tb01421.x

[68] Anderson, J.C., Rungtusanatham, M. and Schroeder, R.G. (1994) A Theory of Quality Management Underlying the Deming Management Method. Academy of Management Review, 19, 472-509. https://doi.org/10.5465/amr.1994.9412271808 
[69] Ahire, S.L., Golhar, D.Y. and Walter, M.A. (1996) Development and Validation of TQM Implementation Constructs. Decision Sciences, 27, 23-56. https://doi.org/10.1111/j.1540-5915.1996.tb00842.x

[70] Black, S.A. and Porter, L.J. (1996) Identification of the Critical Factors of TQM. Decision Sciences, 27, 1-21. https://doi.org/10.1111/j.1540-5915.1996.tb00841.x

[71] Giunipero, L.C. and Vogt, J.F. (1997) Empowering the Purchasing Function: Moving to Team Decisions. International Journal of Purchasing and Materials Management, 33, 8-15.

[72] Carter, C.R., Kale, R. and Grimm, C.M. (2000) Environmental Purchasing and Firm Performance: An Empirical Investigation. Transportation Research Part E: Logistics and Transportation Review, 36, 219-228. https://doi.org/10.1016/S1366-5545(99)00034-4

[73] Lascelles, D.M. and Dale, B.G. (1989) The Buyer-Supplier Relationship in Total Quality Management. Journal of Purchasing and Materials Management, 25, 10-19. https://doi.org/10.1111/j.1745-493X.1989.tb00477.x

[74] Stuart, F.I. and Mueller, Jr. P. (1994) Total Quality Management and Supplier Partnerships: A Case Study. International Journal of Purchasing and Materials Management, 30, 14-20.

[75] Trent, R.J. and Monczka, R.M. (1999) Achieving World-Class Supplier Quality. Total Quality Management, 10, 927-938. https://doi.org/10.1080/0954412997334

[76] McGinnis, M. and Vallopra, M.R. (1999) Purchasing and Supplier Involvement in Process Improvement: A Source of Competitive Advantage. Journal of Supply Chain Management, 35, 42-50. https://doi.org/10.1111/j.1745-493X.1999.tb00243.x

[77] Carter, J.R. and Miller, J.G. (1989) The Impact of Alternative Vendor/Buyer Communication Structures on the Quality of Purchased Materials. Decision Sciences, 20, 759-776. https://doi.org/10.1111/j.1540-5915.1989.tb01418.x

[78] Stanley, L.L. and Wisner, J.D. (1998) Internal Service Quality in Purchasing: An Empirical Study. International Journal of Purchasing and Materials Management, 34, 50-60. https://doi.org/10.1111/j.1745-493X.1998.tb00295.x

[79] Wisner, J. and Stanley, L.L. (1999) Internal Relationships and Activities Associated with High Levels of Purchasing Service Quality. Journal of Supply Chain Management, 35, 25-31. https://doi.org/10.1111/j.1745-493X.1999.tb00059.x

[80] McIvor, R. and McHugh, M. (2000) Partnership Sourcing: An Organization Change Management Perspective. Journal of Supply Chain Management, 36, 12-20. https://doi.org/10.1111/j.1745-493X.2000.tb00247.x

[81] Womack, J.P. and Jones, D.T. (2003) Lean Thinking. 2nd Edition, The Free Press, New York, NY.

[82] Atkinson, W. (2006) Centralizing Delivers New Procurement Value. Purchasing, 135, 25-26.

[83] Ellram, L.M. and Edis, O. (1996) A Case Study of Successful Partnering Implementation. International Journal of Purchasing and Materials Management, 32, 20-28. https://doi.org/10.1111/j.1745-493X.1996.tb00227.x

[84] Ellram, L.M., Siferd, S.P., Zsidisin, G. and Stanly, M. (2002) The Impact of Purchasing and Supply Chain Management Activities on Corporate Success. Journal of Supply Chain Management, 38, 4-17. https://doi.org/10.1111/j.1745-493X.2002.tb00116.x

[85] Bellingkrodt, S. and Wallenburg, C.M. (2015) The Role of Customer Relations for Innovativeness and Customer Satisfaction: A Comparison of Service Industries. The 
International Journal of Logistics Management, 26, 254-274. https://doi.org/10.1108/IJLM-06-2012-0038

[86] Vafeas, M. (2015) Account Manager Turnover and the Influence of Context: An Exploratory Study. Journal of Business and Industrial Marketing, 30, 72-82. https://doi.org/10.1108/JBIM-04-2012-0064

[87] Kembro, J. and Selviaridis, K. (2015) Exploring Information Sharing in the Extended Supply Chain: An Interdependence Perspective. Supply Chain Management: An International Journal, 20, 455-470. https://doi.org/10.1108/SCM-07-2014-0252

[88] Govindarajan, V. (1986) Decentralization, Strategy and Effectiveness of Strategic Business Units in Multibusiness Organizations. Academy of Management Review, 11, 844-856. https://doi.org/10.5465/amr.1986.4284099

[89] Miller, D. (1987) Strategy Making and Structure: Analysis and Implications for Performance. Academy of Management Journal, 30, 7-32.

[90] Mintzberg, H. (1992) Structure in Fives: Designing Effective Organizations. Prentice Hall, Upper Saddle River, NJ.

[91] Brookshaw, T. and Terziovski, M. (1997) The Relationship between Strategic Purchasing and Customer Satisfaction within a Total Quality Management Environment. Benchmarking for Quality Management and Technology, 4, 244-258. https://doi.org/10.1108/14635779710195096

[92] Narasimhan, R. and Carter, J.R. (1998) Linking Business Unit and Material Sourcing Strategies. Journal of Business Logistics, 19, 155-171.

[93] González, B.J. (2007) A Theory of Purchasing's Contribution to Business Performance. Journal of Operations Management, 25, 901-917. https://doi.org/10.1016/j.jom.2007.02.001

[94] Kim, M., Suresh, N.C. and Kocabasoglu-Hillmer, C. (2015) A Contextual Analysis of the Impact of Strategic Sourcing and E-Procurement on Performance. Journal of Business and Industrial Marketing, 30, 1-16. https://doi.org/10.1108/JBIM-01-2012-0010

[95] Ashenbaum, B. and Maltz, A. (2017) Purchasing-Logistics Integration and Supplier Performance: An Information Processing View. The International Journal of Logistics Management, 28, 379-397. https://doi.org/10.1108/IJLM-07-2014-0113

[96] Ward, I.H. (1963) Hierarchical Grouping to Optimize an Objective Function. Journal of the American Statistical Association, 58, 234-244. https://doi.org/10.1080/01621459.1963.10500845

[97] Central Bank of Jordan (2018) The Hashemite Kingdom of Jordan: Economic and Financial Data. http://www.cbj.gov.jo/echobusv3.0/systemassets/new\%20html/nsdp_2010.html

[98] Philips, J. (1981) Assessing Measurement Error in Key Informant Reports: A Methodological Note on Organizational Analysis in Marketing. Journal of Marketing Research, 18, 395-415. https://doi.org/10.1177/002224378101800401

[99] De Vellis, R.F. (2009) Scale Development. 2nd Edition, Sage Publications, Thousand Oaks, CA.

[100] Yin, R.K. (2009) Case Study Research: Design and Methods. 4th Edition, Sage Publications, Thousand Oaks, CA.

[101] Stock, G.N., Greis, N.P. and Kasarda, J.D. (2000) Enterprise Logistics and Supply Chain Structure: The Role of Fit. Journal of Operations Management, 18, 531-547. https://doi.org/10.1016/S0272-6963(00)00035-8

[102] Li, S.H., Bhanu, R., Ragu-Nathanb, T. and Subba, R.S. (2006) The Impact of Supply 
Chain Management Practices on Competitive Advantage and Organizational Performance. Omega, 34, 107-124. https://doi.org/10.1016/j.omega.2004.08.002

[103] Gusman, N., Lim, K., Teong, S. and Norezam, O. (2013) Impact of Lean Practices on Operations Performance and Business Performance: Some Evidence from Indonesian Manufacturing Companies. Journal of Manufacturing Technology Management, 24, 1019-1050. https://doi.org/10.1108/JMTM-03-2012-0027

[104] Armstrong, S.J. and Overton, T.S. (1977) Estimating Nonresponse Bias in Mail Surveys. Journal of Marketing Research, 14, 396-402. https://doi.org/10.1177/002224377701400320

[105] Ketchen, D.J. and Shook, C.L. (1996) The Application of Cluster Analysis in Strategic Management Research: An Analysis and Critique. Strategic Management Journal, 17, 441-458.

https://doi.org/10.1002/(SICI)1097-0266(199606)17:6<441::AID-SMJ819>3.0.CO;2-G

[106] Nunnally, J. (1978) Psychometric Theory. McGraw-Hill, New York, NY.

[107] Bigliardi, B. and Bottani, E. (2010) Performance Measurement in the Food Supply Chain: A Balanced Scorecard Approach. Facilities, 28, 249-260.

https://doi.org/10.1108/02632771011031493

[108] Friedli, T., Goetzfried, M. and Basu, P. (2010) Analysis of the Implementation of Total Productive Maintenance, Total Quality Management and Just-In-Time in Pharmaceutical Manufacturing. Journal of Pharmaceutical Innovation, 5, 181-192. https://doi.org/10.1007/s12247-010-9095-x

[109] Abernathy, F. (2004) Marketing, Merchandising and Retailing: The Role of Intermediaries in Global Value Chains. Presentation at the University of Washington, Washington DC, 6 June 2004.

[110] Venkatraman, N. (1989) The Concept of Fit in Strategy Research: Toward Verbal and Statistical Correspondence. Academy of Management Review, 14, 423-444. https://doi.org/10.5465/amr.1989.4279078

[111] Chan, E., Huff, L., Barclay, W. and Copeland, G. (1997) Business Strategic Orientation, Information Systems Strategic Orientation and Strategic Alignment. Information Systems Research, 8, 125-150. https://doi.org/10.1287/isre.8.2.125 


\section{Appendix A}

\section{Part I}

On a scale of $1=$ "extremely low use of initiative", to $5=$ "extremely high use of initiative", indicate your firm's position on each of the following practices.

Item Description $\quad$ Not Used (1) (2) (3)

A. Cost Practices (CP)

CP1: The purchasing department is actively involved in evaluating and redesigning its own processes in order to reduce costs and efforts.

CP2: The purchasing department is actively involved in redesigning its own processes in order to better fit with suppliers' processes.

CP3: Your purchase IT system has a search facility to help identify the item you wish to purchase, e.g. based on keywords.

CP4: Your purchase IT system has automatic filling-in of items on the purchase order. For example, entering the required item number might automatically identify the supplier, and enter the suppliers' details on the order.

CP5: Your purchase IT system has an automatic issue of an order by fax or e-mail. Once the order is approved, the computer should be able to send it to the supplier electronically without the need to print off a hardcopy and send it by post.

CP6: For non-high value, low risk purchased item, your purchasing procedures are not to inspect purchased item.

CP7: For certain items, once a contract is signed, end-users, appropriately authorized, can identify the items they need from the contract and communicate their requirements directly to the suppliers. Accordingly, there is no need for them to seek approval from purchasing or from anyone else before doing so.

CP8: Your organization nominates staff within your company (these could be both buyers and end-users) to be issued purchasing cards. These can have an upper limit on individual transactions and on total expenditure per month.

CP9: When purchasing a certain item, Your purchasing procedures allow you to set up an account with a supplier that allows you to make purchases via the suppliers' Internet website.

CP10: Your suppliers can issue consolidated billing in order to reduce the frequency of invoices, thus reducing the amount of time and effort involved in processing these invoices and making payment.

CP11: Before making a purchase, you use benchmarking data to compare prices.

CP12: The purchasing department is actively involved in value analysis/ engineering processes with suppliers to achieve savings from design optimizations.

CP13: Your organization agrees with suppliers to work jointly on total cost reduction initiatives.

B. Quality Practices (QP)

QP1: Purchasing management is actively involved in activities to promote quality in the company.

QP2: Purchasing management communicates to purchasing personnel that quality is the most important goal.

QP3: Performance evaluation for purchasing management is based on quality performance (materials purchased defects rate, degree of internal customer satisfaction).

QP4: Quality is the most important criterion in the selection and evaluation of suppliers. 


\section{Continued}

QP5: Purchasing personnel participate with quality and/ or production personnel in determining materials specifications.

QP6: Purchasing personnel collaborate with production/ manufacturing personnel in solving production problems.

QP7: Purchasing is involved in the company's new product development process.

QP8: We visit suppliers' factories to assess their facilities; suppliers are recognized and rewarded for materials quality improvement.

QP9: We collect information (data) about quality performance (suppliers' rejection rate, degree of internal customer satisfaction).

QP10: Suppliers participate in the company's new product development process.

C. Availability (AP)

AP1: Our demand forecasts are inserted as slot requirements into the suppliers' production schedule, thereby reducing the risk of delayed delivery, and providing a basis for making more reliable contractual commitments to suppliers.

AP2: You assign a supplier account manager in order to provide a focal point in your company to manage the relationship with the supplier.

AP3: The purchasing department is actively involved in evaluating and redesigning its own processes to adjust its processes to fit in better with the suppliers' processes. (reduce lead-time to delivery).

AP4: Your company and suppliers pool knowledge and expertise in order to reduce lead-time to delivery.

\section{Part II}

1. Strategic Intent: The following statements help us understand your business strategy. Please indicate by ticking the appropriate box the extent to which you agree with each statement as best reflecting your company's business strategy in the past two years, on a scale of $1=$ "least important" to $5=$ "extremely important".

A. Cost:

I. We attempt to be ahead of our competitors by cheaper pricing of our products.

II. We constantly drive to improve the efficiency of our processes.

B. Quality:

I. We attempt to be ahead of our competitors by quality products rather than price.

II. We attempt to be ahead of our competitors by providing quality products to our customers.

C. Availability:

I. We attempt to be ahead of our competitors by satisfying our customers in the right quantity at the right time.

II. We attempt to be ahead of our competitors by delivering our products quicker to our customers.

2. Business Performance: Please circle the appropriate number that best indi- 
cates your firm's overall performance, where $1=$ significant decrease, $2=$ decrease, 3 = same as before, $4=$ increase, and $5=$ significant increase.

BP1: The growth of market share.

BP2: The growth of sales.

BP3: Overall competitive position.

\section{Appendix B: Sample Calculation of the Alignment Scores}

Consider, for example, that the business strategy emphasis in a given firm on the three competitive strategies is as follows: Cost $=3.00$; Quality $=3.50$; Availability $=4$. The purchasing cluster practice of that same firm, however, rated the three respective practices as follows: Cost-Practice $=2.00$; Quality-Practice $=4.00$; and Availability-Practice $=3.00$.

Based on the above scores, the Strategic-Fit for the given firm is calculated as:

Business-Purchasing alignment (Cost) $=3.00 * 2.00=6.00$

Business-Purchasing alignment (Quality) $=3.50 * 4.00=14.00$

Business-Purchasing alignment (Availability) $=4.00 * 3.00=12.00$

Overall Strategic-Fit $=\operatorname{SQRT}(6.00 * 14.00 * 12.00)=31.75$ 